\title{
Frequency and Seasonal Distribution of Pear Psylla Infected with the Pear Decline Phytoplasma in California Pear Orchards
}

\author{
C. L. Blomquist and B. C. Kirkpatrick
}

Department of Plant Pathology, University of California, Davis 95616.

Accepted for publication 6 June 2002.

\begin{abstract}
Blomquist, C. L., and Kirkpatrick, B. C. 2002. Frequency and seasonal distribution of pear psylla infected with the pear decline phytoplasma in California pear orchards. Phytopathology 92:1218-1226.

Pear decline (PD) is an important disease of Pyrus communis fruiting cultivars in Europe, Asia, and the Americas. PD is caused by a phloemlimited phytoplasma that, in California, is transmitted from diseased to healthy trees by pear psylla, Cacopsylla pyricola. The percentage of phytoplasma-infected pear psylla has never been assessed in the United States in field-collected insects. Pear psylla were collected monthly from PD-infected trees from three orchards in northern California. Individual

quantitative DNA hybridization and PD phytoplasma-specific polymerase chain reaction (PCR) assays. The percentage of infected psylla ranged from 0 to $45 \%$ depending on the orchard, the month and year collected, and the method of detection. The PD phytoplasma was detected in both the winterform and summerform pear psylla. Significantly more infected psylla were detected with PCR than with DNA hybridization analysis in two of the three orchards. The number of PD phytoplasma per pear psylla was estimated to range from $1 \times 10^{6}$ to $8.2 \times 10^{7}$. The percentage of PDinfected pear psylla found in the three northern California pear orchards suggests that both winterform and summerform pear psylla could be important in the transmission of PD.
\end{abstract} psylla were tested for the presence of PD phytoplasma, using both a
Phytoplasmas are small, wall-less prokaryotes, which infect both their plant host and insect vector. The pear decline (PD) phytoplasma causes an important disease in Pyrus communis fruiting cultivars in Europe, Asia, and the Americas. The severity of PD depends on the rootstock on which the cultivar is grafted. Those trees grafted on selections of $P$. communis, $P$. betulifolia, $P$. calleryana, and Cydonia oblongata (quince) become infected by PD, but they are the most tolerant of the PD phytoplasma and display the fewest decline symptoms both in the crown and at the graft union. Those grafted on Asian rootstocks such as $P$. ussuriensis and $P$. serotina are the most susceptible, showing a quick or progressive decline of the tree, often with a distinct brown line present at the graft union. These rootstocks are no longer used in areas where PD is present because of their susceptibility $(29,37)$. PD is transmitted by pear psylla, Cacopsylla pyricola, in North America (15) and the United Kingdom (10) and probably by C. pyri in Spain (2) and Italy (5).

The pear psylla (Cacopsylla pyricola) has two morphologically distinct adult stages: a larger, darker overwintering winterform, and a smaller, reddish-brown summerform (24). There are four or five generations of summerform and one generation of winterform psylla each year in northern California (22). The summerform is found from June to October, whereas the winterform is found from September to May (Fig. 1). The summerform and the winterform overlap from September through early November. During the rest of the year, one form or the other predominates. In late summer, as day length shortens, the eggs laid by the summerform psylla develop into winterform adult psylla. Some of these winterform adults leave pear orchards in late fall and overwinter on other vegetation nearby, with a portion of the winterform psylla remaining in the pear orchards during the winter months. Winterform female psylla undergo an ovarian diapause, which requires a

Corresponding author: B. C. Kirkpatrick; E-mail address: bckirkpatrick@ucdavis.edu

Publication no. P-2002-0912-01R

(C) 2002 The American Phytopathological Society period of low temperatures before its eggs can develop (19). After the diapause period has ended and temperatures begin to warm (usually in February in California), the female psylla return to pear trees and lay their eggs on the emerging pear leaf buds (14). These eggs then develop into the summerform psylla. Both the winter and summerforms can transmit the PD phytoplasma to healthy pear trees (C. L. Blomquist and B. C. Kirkpatrick, unpublished data).

Until recently, there were no rapid methods for detecting the PD phytoplasma in either pear psylla or pear trees. With the development of PD clade-specific polymerase chain reaction (PCR) primers based on the 16S-23S rRNA spacer region (30), and a PDspecific chromosomal DNA hybridization probe (13), large numbers of field-collected psylla could be tested for the PD phytoplasma, and the frequency of PD-infected psylla from the field could be estimated. Using PCR analyses on pear psylla collected from pear trees in the United Kingdom, Davies et al. (8) found seasonal differences in the percentage of pear psylla containing the PD phytoplasma. These researchers also detected PD phytoplasmas in overwintering winterform pear psylla. The objectives of this study were to determine if the PD phytoplasma overwintered in the adult pear psylla in California and approximately what percentage of pear psylla feeding on PD-infected pear trees became infected with the PD phytoplasma. We also wanted to determine if there was seasonal variation in the numbers of psylla infected with the PD phytoplasma and estimate the number of PD phytoplasmas in infected pear psylla.

\section{MATERIALS AND METHODS}

Locations and properties of pear orchards used in this study. Three commercial orchards with a history of PD and pear psylla control problems were chosen for this study. One of these orchards (CV) was located in central California near Suisun; the two other orchards, FH1 and FH2, were located within a mile of each other, in the foothills of the Sierra Nevada near Camino, CA, approximate elevation 1,068 $\mathrm{m}$ (3,500 feet). Pear trees in CV were cv. Early Anderson, and the trees in FH1 and FH2 were cv. Bartlett. 
Few or no insecticides were applied to the organically farmed CV pear orchard. In contrast, insecticides were applied as necessary for pear psylla and codling moth control in the conventionally managed Sierra Nevada foothills orchards FH1 and FH2. Fifteen trees with possible symptoms of PD were selected randomly from each orchard in each location and tested for the PD phytoplasma using PCR. Vascular tissues within the pear fruit were tested, if available, otherwise leaf midribs were tested for the PD phytoplasma in August 1996. Seven to ten trees out of the fifteen trees tested at each site, tested positive for PD and were chosen as psylla collection sites for this study. Psylla were collected monthly from each PDpositive pear tree for 19 months at CV and 32 months at FH1 and FH2. After 19 months, the CV orchard was removed by the grower.

Pear psylla collection. Each selected PD-infected tree was divided visually into four quadrants. Pear psylla were collected from a limb in each of the four quadrants with a beat tray (4) in the morning when temperatures were cool and pear psylla flight was limited. Each limb was struck four times and all pear psylla landing on the beat tray were aspirated into small cages. Psylla were transported to the lab on ice and stored at $-20^{\circ} \mathrm{C}$ until DNA was extracted for PCR and hybridization analysis.

Establishment of an uninfected psylla colony. To establish a PD-free psylla colony, individual females were placed on Bartlett pear seedlings that were raised from seeds in the growth chamber. Each female psylla was allowed to lay eggs for 2 weeks, and then it was removed from the cage and tested for the PD phytoplasma with PCR. All colonies from PCR-negative females were maintained separately until at least 50 adult progeny were tested for PD by PCR. Colonies having PCR-positive females were destroyed. The remaining progeny in three colonies that had 50 PCR-negative adults were pooled and subsequently maintained on healthy Bartlett pear seedling trees in a growth chamber separate from the one with PD-infected pear psylla. Pear seedling trees in the uninfected colony were periodically checked by PCR to insure that the colony was free of the PD phytoplasma. Healthy psylla colonies were kept in growth chambers at $22^{\circ} \mathrm{C}$ on a 16-h light and 8-h dark cycle. Samples of healthy psylla colonies were periodically tested by PCR to insure that the psylla used in experiments were not infected with PD.

DNA extraction. Total DNA was extracted from individual pear psylla according to the method of Zhang et al. (39). Briefly, individual psylla were quick-frozen in microfuge tubes by dipping them in liquid nitrogen. The frozen insects were then ground with a glass pestle. Two hundred fifty microliters of cetyltrimethylammonium bromide (CTAB) buffer was added and the mixture was incubated in a $55^{\circ} \mathrm{C}$ water bath for $30 \mathrm{~min}$. An equal volume of chloroform/isoamyl alcohol (24:1) was added, vortexed until homogeneous, and centrifuged at $14,000 \times g$ for $10 \mathrm{~min}$. Nucleic acids in the supernatant were precipitated with isopropanol and collected by centrifugation. The pellets were vacuum-dried, and psylla DNA was suspended in $20 \mu \mathrm{l}$ of distilled water. DNA was extracted from $1 \mathrm{~g}$ of the phloem-rich areas from the pear fruit core by a phytoplasma enrichment technique (18), and the final DNA pellet was suspended in $100 \mu$ of water. When no fruit was available, DNA was extracted from $1 \mathrm{~g}$ of leaf midribs or stem phloem scrapings by the same method.

PCR analysis of plant and psylla DNA. Primers p1 and PYLR, based on sequences of the 16S rRNA and 16/23S rRNA spacer region, were used in PCR assays to detect the PD phytoplasma in pear psylla and pear trees (30). Healthy pear psylla taken from the uninfected laboratory colony and healthy pear phloem scrapings were used as negative controls. Psylla reared on PD-infected pear trees and DNA extracted from phloem scrapings of PD-infected pear trees were used as positive controls. Two microliters of psylla DNA (10 ng) was used as the template for each PCR reaction. Thermocycling parameters for primers $\mathrm{p} 1$ and PYLR were identical to those described by Smart et al. (30). PCR was performed in a $30-\mu \mathrm{l}$ reaction volume containing $1 \times \mathrm{PCR}$ buffer (Applied Biosystems, Foster City, CA), $0.5 \mu \mathrm{M}$ each primer, $150 \mu \mathrm{M}$ each $\mathrm{dNTP}$, and 1 unit of AmpliTaq polymerase (Applied Biosystems). Thermocycling parameters consisted of 1 cycle of $5 \mathrm{~min}$ at $94^{\circ} \mathrm{C}$ followed by 35 cycles of $94^{\circ} \mathrm{C}$ for $1 \mathrm{~min}$, $53^{\circ} \mathrm{C}$ for $1 \mathrm{~min}$, and $72^{\circ} \mathrm{C}$ for $2 \mathrm{~min}$. The 35 cycles were followed by one extension cycle of $8 \mathrm{~min}$ at $72^{\circ} \mathrm{C}$.

Hybridization analyses with a PD-specific chromosomal probe, pCPD-M10. CPD-M10 is a cloned 1.6-kb fragment of the PD chromosome. It contains three open reading frames that share homology and gene order with putative sugar transport genes in Mycoplasma genitalium (13). CPD-M10 was amplified by PCR with primers fCPD and $\mathrm{rCPD}(13,21)$ from PD-infected pear DNA, and cloned with the TOPO TA Cloning System (Invitrogen, Carlsbad, CA). pCPD-M10 was digested with EcoRI to release CPD-M10, and the fragment was gel-purified (Prep-A-Gene; BioRad, Hercules, CA). The purified CPD-M10 DNA was quantified with a minifluorometer (TKO 100; Amersham Biosciences, Piscataway, $\mathrm{NJ}$ ) before being used as a standard in dot blot analysis or as a hybridization probe.

Dot and Southern blot hybridization analysis. Purified CPDM10 DNA was diluted in $0.5 \times$ TE buffer $(10 \mathrm{mM}$ Tris plus $1 \mathrm{mM}$ EDTA, pH 7.6) and $6 \times \mathrm{SSC}(1 \times \mathrm{SSC}$ is $0.15 \mathrm{M} \mathrm{NaCl}$ plus $0.015 \mathrm{M}$ sodium citrate), denatured at $95^{\circ} \mathrm{C}$ for $8 \mathrm{~min}$, and applied to a reinforced nitrocellulose membrane (Schleicher and Schuell, Keene, $\mathrm{NH}$ ) with dot blot apparatus (Invitrogen) in the following amounts: 500, 125, 62.5, 31.3, 15.6, 7.8, and 3.9 pg. Each standard amount of insert DNA was applied in triplicate on each dot blot membrane. Using linear regression analysis, the average hybridization signal associated with each of the CPD-M10 standards was used to generate a standard curve. Psylla DNA samples for dot blot analysis were denatured and applied to the nitrocellulose membrane as described for the standards above. Ninety percent of the psylla DNA (approximately $90 \mathrm{ng}$ ) from the single insect extractions was applied per sample onto a reinforced nitrocellulose membrane. Membranes were air dried and baked at $80^{\circ} \mathrm{C}$ for $1.5 \mathrm{~h}$. Blots were prehybridized in $50 \%$ formamide with Denhardt's buffer (27) for at least $2 \mathrm{~h}$ at $42^{\circ} \mathrm{C}$, and hybridized overnight at $42^{\circ} \mathrm{C}$ in the same buffer with $100 \mathrm{ng}$ of CPD-M10 random primerlabeled with $\alpha-{ }^{32} \mathrm{P}-\mathrm{dATP}$ as the hybridization probe (11). Membranes were washed once for $30 \mathrm{~min}$ and once for $15 \mathrm{~min}$ at $55^{\circ} \mathrm{C}$ in $0.2 \times \mathrm{SSC}$ containing $1 \mathrm{~g}$ of sodium dodecyl sulfate per liter.

For Southern blots, 150 to $200 \mathrm{ng}$ of DNA from groups of psylla (generally 20 to 30 per group) was digested overnight with the appropriate restriction endonuclease at $37^{\circ} \mathrm{C}$ according to manufacturer's recommendations. DNA restriction fragments were fractionated by electrophoresis in $1 \%$ agarose gels in Tris-acetateEDTA buffer. DNA was denatured and transferred onto nitrocellulose membranes according to standard protocols (27). CPD-M10 DNA was ${ }^{32} \mathrm{P}$-labeled, and blots were hybridized and washed as described previously for dot blot analyses.

Quantification of PD phytoplasma DNA. Phosphoimage analysis was used to quantify the amount of PD DNA on the membranes, because when an imaging screen is exposed to a wide

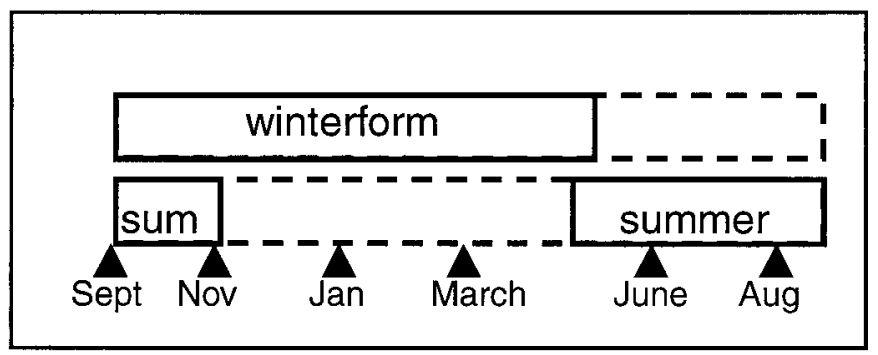

Fig. 1. Diagram showing the months of the year when winterform and summerform pear psylla are present in northern California orchards. Sum, summer $=$ summerform. Winterform and summerform pear psylla are found together from September to November. 
range of DNA concentrations, the signal produced remains linear and does not saturate (16). Membranes hybridized with ${ }^{32} \mathrm{P}$-labeled probes were exposed to a phosphoimaging screen (Fuji Photofilm, Tokyo) for 2 to $3 \mathrm{~h}$. Signal strength was measured either on the BAS 1000 phosphoimaging system (Fuji Photofilm) and analyzed using MacBAS 2.0 software (Fuji Photofilm), or measured on the Storm 820 (Amersham Biosciences) using Image Quant 5.0 software (Amersham Biosciences).

Psylla DNA samples were considered positive for PD phytoplasma DNA if the signal was greater than either the 3.9-pg standard or twice the background, whichever was greater. When available, 36 psylla DNA samples were extracted for each monthly time point. Otherwise, the total number of psylla collected on a given day were extracted. Hybridization results and PCR analysis of psylla samples were scored independently, such that a few samples that were positive by PCR were not necessarily positive by hybridization, and vice versa. The numbers of hybridizationpositive insects in which the amount of PD phytoplasma was quantified was 84 from $\mathrm{CV}, 42$ from $\mathrm{FH} 2$, and 30 from FH1.
Estimation of the number of PD phytoplasmas per pear psylla. The amount of CPD-M10 DNA in each PD-infected psylla was calculated by comparing the hybridization signal from the field-collected, PD-infected, psylla with the standard curve of di-

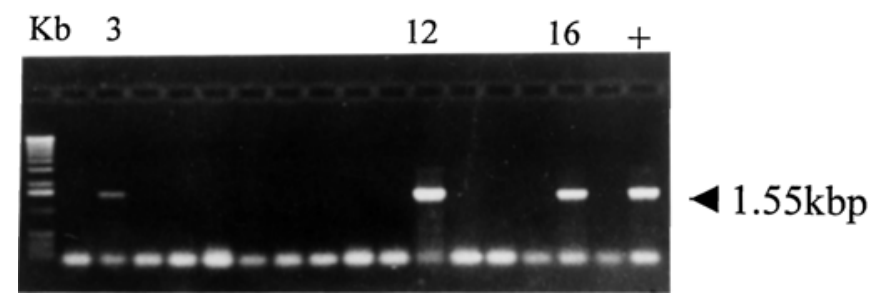

Fig. 3. A representative agarose gel showing polymerase chain reaction (PCR) amplification products from field-collected pear psylla using pear decline-specific primers P1 and PYLR. Lane Kb, 1-kb ladder; lanes 2 to 17, PCR reactions for DNA from individual pear psylla; and lane 18, positive control. The lanes with no product contain DNA from psylla with no detectable pear decline phytoplasmas.

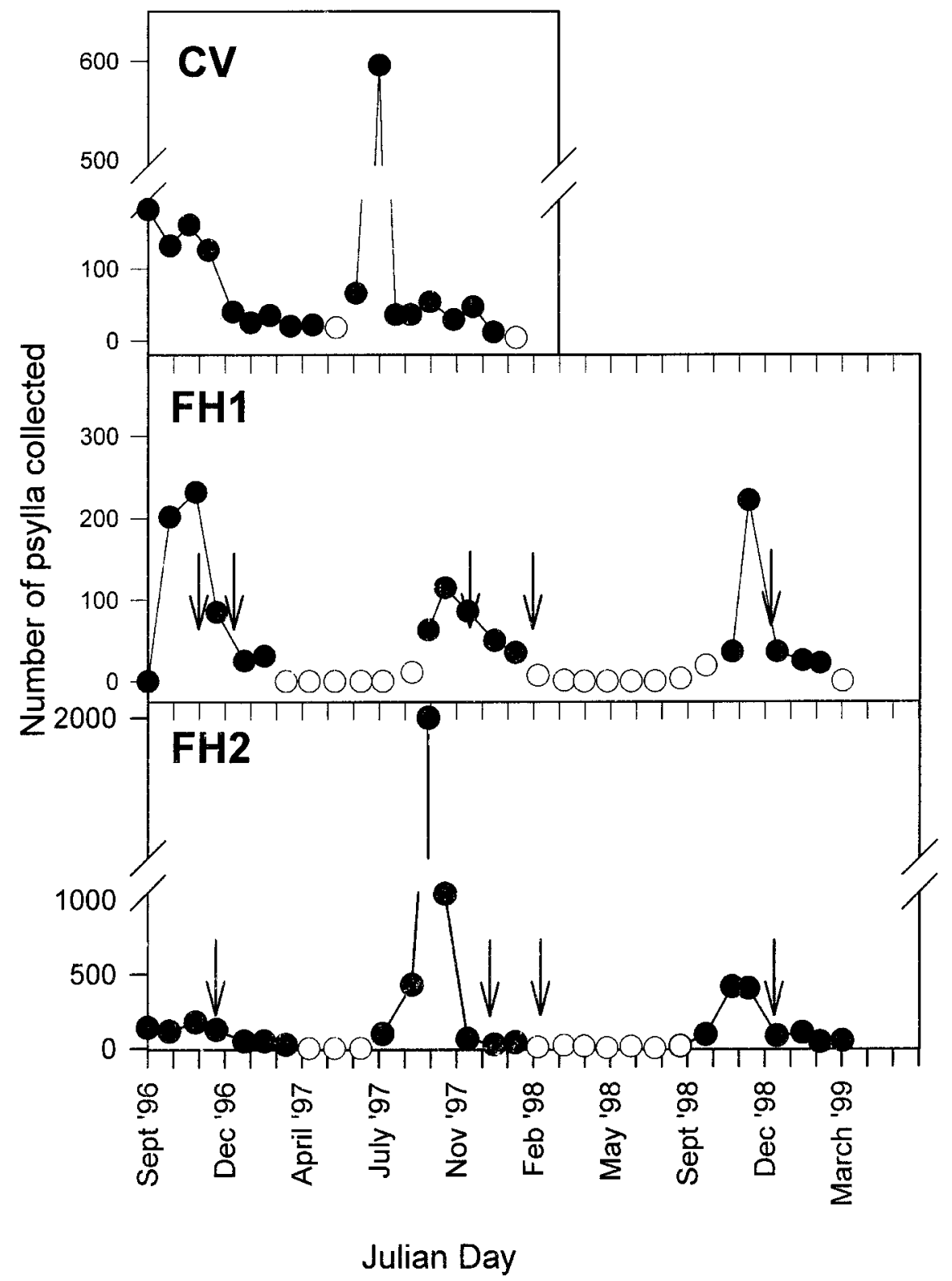

Fig. 2. Total number of pear psylla collected from four limbs of 7 to 10 pear trees in Central Valley (CV) and Sierra foothills (FH1 and FH2) orchards from September 1996 to March 1998 (CV) and to March 1999 (FH1 and FH2). Orchard CV was removed by the grower in April 1998. Open circles indicate the dates in which fewer than 20 psylla were collected. Arrows indicate approximate dates that growers applied insecticidal sprays. Note the differences in the $y$-axis scales for each orchard. 


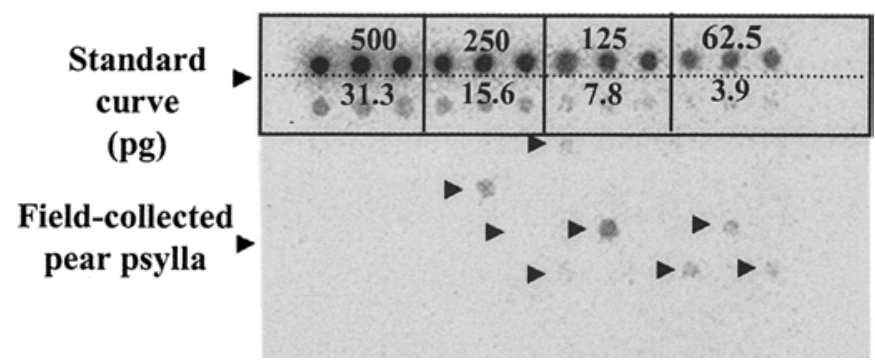

Fig. 4. A representative quantitative hybridization analysis of 72 DNA samples of individual field-collected pear psylla. Psylla DNAs were hybridized with a ${ }^{32} \mathrm{P}$-labeled pear decline-specific cloned chromosomal probe, CPD-M10. Hybridized dot blot membranes were exposed to a phosphoimaging screen and by comparing the hybridization signal from the individual infected pear psylla to the signal produced by the standard curve of diluted CPD-M10, the picograms of CPD-M10 per psylla were estimated. The value was used to estimate the number of phytoplasmas per pear psylla. Arrows indicate those pear psylla that were infected with detectable quantities of the pear decline phytoplasma. Psylla were considered to be infected with the pear decline phytoplasma if the signal was greater than the 3.9-pg standard or twice the background, whichever was greater. luted CPD-M10. Using the molecular weight of the CPD-M10 insert, which has been completely sequenced (13), the number of moles of single-stranded CPD-M10 in a psylla was calculated from the picograms obtained from the standard curve. This value was multiplied by Avogadro's number $\left(6.02 \times 10^{23}\right)$ to give the number of molecules of single-stranded CPD-M10, and divided by 2 to give the number of double-stranded DNA molecules of CPDM10 (or PD phytoplasma chromosomes) present in a psylla. The total was divided by 0.9 to compensate for only measuring $90 \%$ of the sample by hybridization analysis because the other $10 \%$ of the sample DNA was used for PCR analysis. The final estimate of the number of PD phytoplasmas per pear psylla assumes that (i) there is only a single copy of CPD-M10 in the PD genome, (ii) there is one chromosome per PD phytoplasma, (iii) $100 \%$ of the PD DNA was extracted from the psylla, and (iv) $100 \%$ of the DNA was applied to the nitrocellulose membrane bound.

Statistical analysis. Proportions of psylla that were hybridization- and PCR-positive for the PD phytoplasma were compared using chi-square analysis for comparison of proportions in paired samples (31).

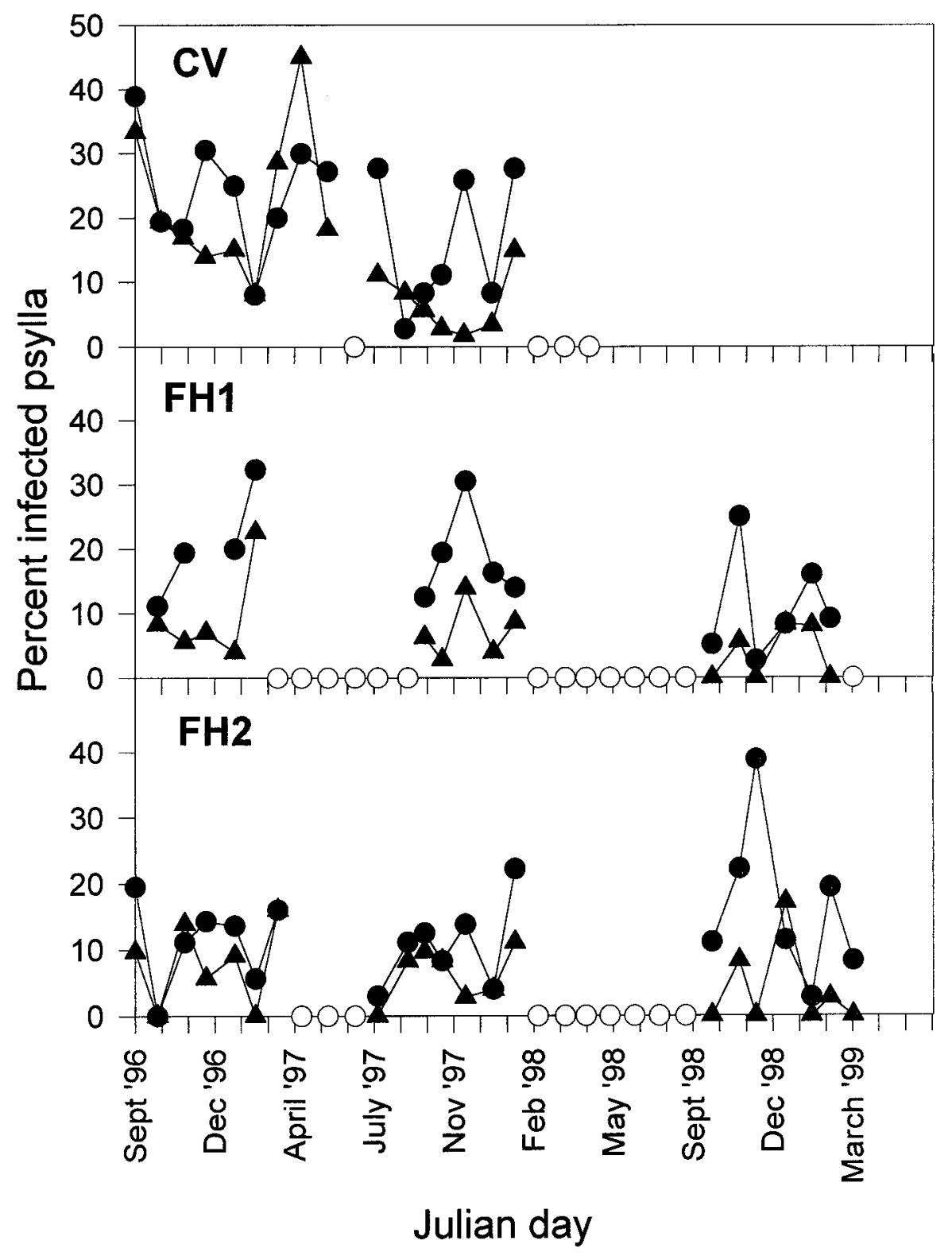

Fig. 5. Percentage of field-collected pear psylla infected with the pear decline (PD) phytoplasma in orchards CV, FH1, and FH2. PD phytoplasma infection was measured by polymerase chain reaction $(\bullet)$ and DNA hybridization analysis $(\mathbf{\Lambda})$. $\bigcirc$, dates when fewer than 20 psylla were collected. 


\section{RESULTS}

Pear psylla collections. The number of pear psylla collected varied among orchards and with the season (Fig. 2). Psylla were consistently collected in the organically farmed CV orchard from September 1996 to March 1998. In the Sierra foothill orchards, FH1 and FH2, few or no psylla were collected from March to June in all years because a delayed dormant insecticidal spray was applied in March of each year (Fig. 2). In July through October 1997, large numbers of summerform psylla were collected from $\mathrm{CV}$ and FH2. Populations peaked in August in CV and in September in FH2. This increase did not occur in FH1 where the grower applied an insecticide. The number of psylla collected increased from September until either October (1997, FH1; and 1998, FH2) or November (1996 and 1998, FH1; 1996, FH2; and 1996 and 1997, CV) (Fig. 2).

PCR and hybridization analysis of pear psylla. A representative agarose gel showing the 1.55 -kb fragment amplified by primers p1 and PYLR is pictured in Figure 3. The intensity of the amplified PD-phytoplasma DNA varied among psylla (Fig. 3, lane 3 versus lanes 12 and 16). A representative computer printout of a digitized image of a psylla dot blot hybridization using phosphoimaging analysis for the detection of CPD-M10 is shown in Figure 4.

The percentage of pear psylla infected with the PD phytoplasma showed no clear seasonal trend (Fig. 5). PD-infected pear psylla were detected every month of the year that psylla were collected, and PD-phytoplasmas were detected in both winterform and summerform pear psylla. The percentage of PD-infected psylla ranged from $0 \%$ (0/36 in FH2, October 1996) to nearly $45 \%$ (in CV, April 1997). The average percentage of PD-infected pear psylla determined by PCR and hybridization analyses during this study is shown in Table 1. In orchards FH1 and FH2, significantly more PD-infected pear psylla were detected with the PCR method compared with DNA hybridization analysis (Table 1). In CV, PCR detected more PD-infected psylla than DNA hybridization, but the difference was not statistically significant (Table 1).

Evidence that CPD-M10 is a single copy gene. To obtain an accurate estimate of the number of PD phytoplasmas per psylla, the number of CPD-M10 (the probe used in hybridization analysis) copies per PD genome was investigated. Two restriction enzymes that digested outside the CPD-M10 sequence were chosen for Southern blot hybridization analysis. CPD-M10 labeled with ${ }^{32} \mathrm{P}$, hybridized with a single 3.6-kb BglII (Fig. 6, lanes 1, 2, and 4) and a 9.0-kb EcoRI (Fig. 6, lanes 5, 6, and 8) fragment from PDinfected psylla DNA, but not with DNA from healthy psylla (Fig. 6, lanes 3 and 7). A BLASTP search was performed on the three open reading frames present on the CPD-M10 chromosomal frag-

TABLE 1. Percentage of pear psylla collected in the Central Valley (CV) and the Sierra foothills FH1 and FH2 orchards that were infected with the pear decline (PD) phytoplasma

\begin{tabular}{llr}
\hline Orchard & \multicolumn{1}{c}{$\mathrm{PCR}+{ }^{\mathrm{a}}$} & \multicolumn{1}{c}{$\mathrm{Hyb}+{ }^{\mathrm{b}}$} \\
\hline $\mathrm{CV}^{\mathrm{c}}$ & $19.0 \%(117 / 613)$ & $14.8 \%(91 / 613)$ \\
$\mathrm{FH}^{\mathrm{d}}$ & $13.8 \%(80 / 578)$ & $6.4 \%(37 / 578)$ \\
$\mathrm{FH} 2$ & $18.2 \%(124 / 680)$ & $6.9 \%(47 / 680)$ \\
\hline
\end{tabular}

a Individual pear psylla from which a PD-specific 1.55 -kb product was polymerase chain reaction (PCR)-amplified using the PD-specific primers p1 and PYLR. Ten percent of the DNA extracted from an individual psylla was used as PCR template in this test.

${ }^{b}$ Individual pear psylla that hybridized with a ${ }^{32} \mathrm{P}$-labeled PD chromosomal fragment, CPD-M10. Ninety percent of the DNA extracted from an individual psylla was used in this test.

${ }^{c}$ In $\mathrm{CV}$, the proportion of samples positive by PCR is not significantly different from those positive by hybridizaton $\left(X^{2}=3.0 ; 0.1>P>0.5\right)$.

${ }^{\mathrm{d}}$ In FH1 and FH2, the proportion of samples positive by PCR is significantly different from those positive by hybridization $\left(X^{2}=15.1\right.$ and 33.7, respectively) with $P<0.005$ for both comparisons. ment (13). The results of this search showed that a single copy of a homologous operon is present in the $M$. genitalium genome (13). The results of the Southern blot analysis and the BLAST searches are consistent with the CPD-M10 chromosomal fragment being present in only a single copy in the PD phytoplasma genome, because restriction enzyme digests that cut outside the gene resulted in only a single band in Southern blot analysis, and BLAST searches of the CPDM10 protein sequence found only a single copy of the homolog in other mollicutes.

Estimation of the number of PD phytoplasmas in field-collected pear psylla. From 6.4 to $14.8 \%$ of the psylla tested positive by hybridization analysis (Table 1). The number of PD phytoplasmas per pear psylla estimated by quantitative hybridization analysis ranged from $1 \times 10^{6}$ (the limit of detection) to $8.2 \times 10^{7}$ (Fig. 7). Both the number of PD phytoplasma-infected psylla and the titers of PD phytoplasma per psylla varied in each of the orchards (Fig. 7).

The distribution of the hybridization positive pear psylla was not uniform over the year (Fig. 8). In FH1 and FH2 pear orchards, the distribution of the hybridization-positive PD-infected psylla titers was similar in September to March 1996 to 1997, August to March 1997 to 1998, and August to March 1998 to 1999 (Fig. 8). Very few hybridization-positive insects were detected in the foothill orchards (FH1 and FH2) in May, June, and July. In May, June, and July 1997, 22, 18, and 36 psylla, respectively, were tested from CV; 0, 0, and 36 psylla were tested from FH2 in May, June, July, respectively, and no psylla were tested from FH1 during this time period. Even though the sample size was reduced, there was a smaller percentage of PD hybridization positive psylla found in $\mathrm{CV}$ during the late spring and early summer and in orchard $\mathrm{FH} 2$ in July than the other months of the year (Fig. 5); however, this difference was not statistically significant.

\section{DISCUSSION}

The percentage of phytoplasma-infected vectors in previous studies has varied in the vector-phytoplasma species combination studied and the method used for detecting the phytoplasma (Table 2). In England, Davies and Eyre (9) measured the overall percentage of PD phytoplasmas in pear psylla using PCR. They found an

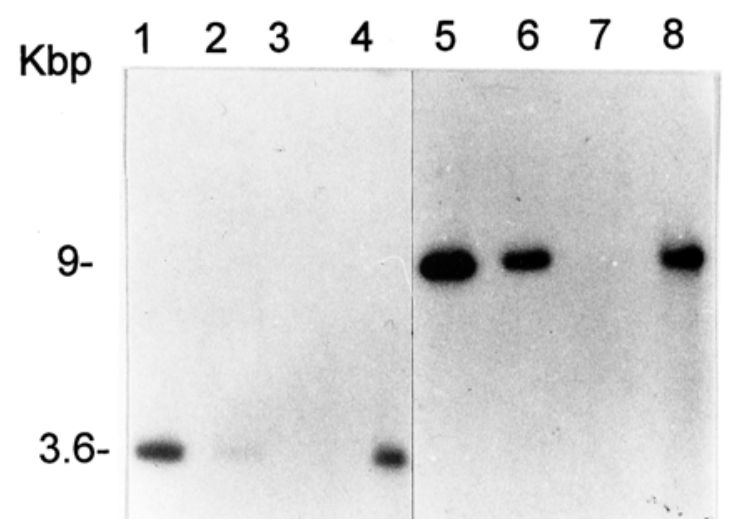

Fig. 6. Southern blot hybridization analysis of total genomic DNA from healthy and pear decline-infected pear psylla digested with BglII (lanes 1 to 4) and EcoRI (lanes 5 to 8) and hybridized with a cloned 1.5-kb fragment of the pear decline phytoplasma genome (CPD-M10). Lanes 1 and 2, $200 \mathrm{ng}$ of DNA from pear psylla each collected from a different abandoned pear decline-infected orchard located in the foothills of the Sierra Nevada (not the maintained orchards used in the main body of this study). Lane 3, $200 \mathrm{ng}$ of pear psylla DNA from a healthy laboratory-reared colony. Lane 4, $150 \mathrm{ng}$ of psylla DNA from a pear decline-infected orchard located in the Central Valley (CV) of California. One-twentieth of the DNA extracted from of a pool of 30 pear psylla was digested, and the DNA was fractionated by agarose electrophoresis, transferred to a membrane, and probed with ${ }^{32} \mathrm{P}-$ labeled CPD-M10. 
overall average of 3 to $5 \%$ (range from $<1$ to $27.7 \%$ ) of the psylla collected off pear trees grafted onto quince rootstocks were infected. Davies and Eyre (9) also found an average of $17 \%$ of the psylla collected from trees grafted on pear seedlings ( $P$. communis) rootstocks were infected with PD phytoplasmas. The percentage of infected psylla sampled from these pear seedling trees was highest in late spring and fall (the end of the winterform and summerform, respectively). In this study, the overall percentage of PD-infected pear psylla, detected by PCR, in northern California ranged from 13.8 to $19 \%$, which was very similar to the pear tree seedling results in England. In contrast to the English study, we saw no clear seasonal trends in the percentage of PD-infected psylla, as measured by PCR. This disparity could be due to differences in climate, scion varieties, and insect biotypes between England and California. The presence of a rootstock (versus an ownrooted tree) may also have influenced PD-phytoplasma titers, which could have affected phytoplasma acquisition and subsequent infection of pear psylla populations. We did see an apparent difference in the percent infection of psylla collected from the Central Valley orchard and the foothill orchards. This difference may be due to the longer, warmer growing season in the Central Valley, but because the study was not replicated in the valley, it is not possible to say if this is true.
Our PD percent infection and titer results imply that both summerform and winterform pear psylla are probably important in the transmission of PD. The high titer winterform pear psylla could act as a source of inoculum "waiting" to transmit the PD phytoplasma into the newly developed pear leaf phloem in the spring and initiate an early infection in the canopy of an uninfected or already PD-infected tree. Psylla-mediated spring infections could happen well before the PD phytoplasma would normally recolonize the upper portion of the tree from overwintering PD phytoplasmas in the roots (28), and such foliar infections might increase the severity of PD. Even though the percentage of infected summerform pear psylla determined by hybridization analysis was low, when huge population increases occur, which happened in the summer of 1997 in orchards CV and FH2, the corresponding increase in numbers of infected insects may result in greater transmission of PD to healthy trees within an orchard.

More PD phytoplasmas were detected in psylla by PCR than hybridization analysis, a result that agrees with other studies. Grapevine yellows-infected periwinkle was detected by PCR with $10^{-6}$ less DNA than was required for detection by DNA hybridization analysis (6). Comparing the detection of grapevine yellows phytoplasma in planthoppers, only $66 \%$ of the PCR positives were also positive by enzyme-linked immunosorbent assay (35). PCR
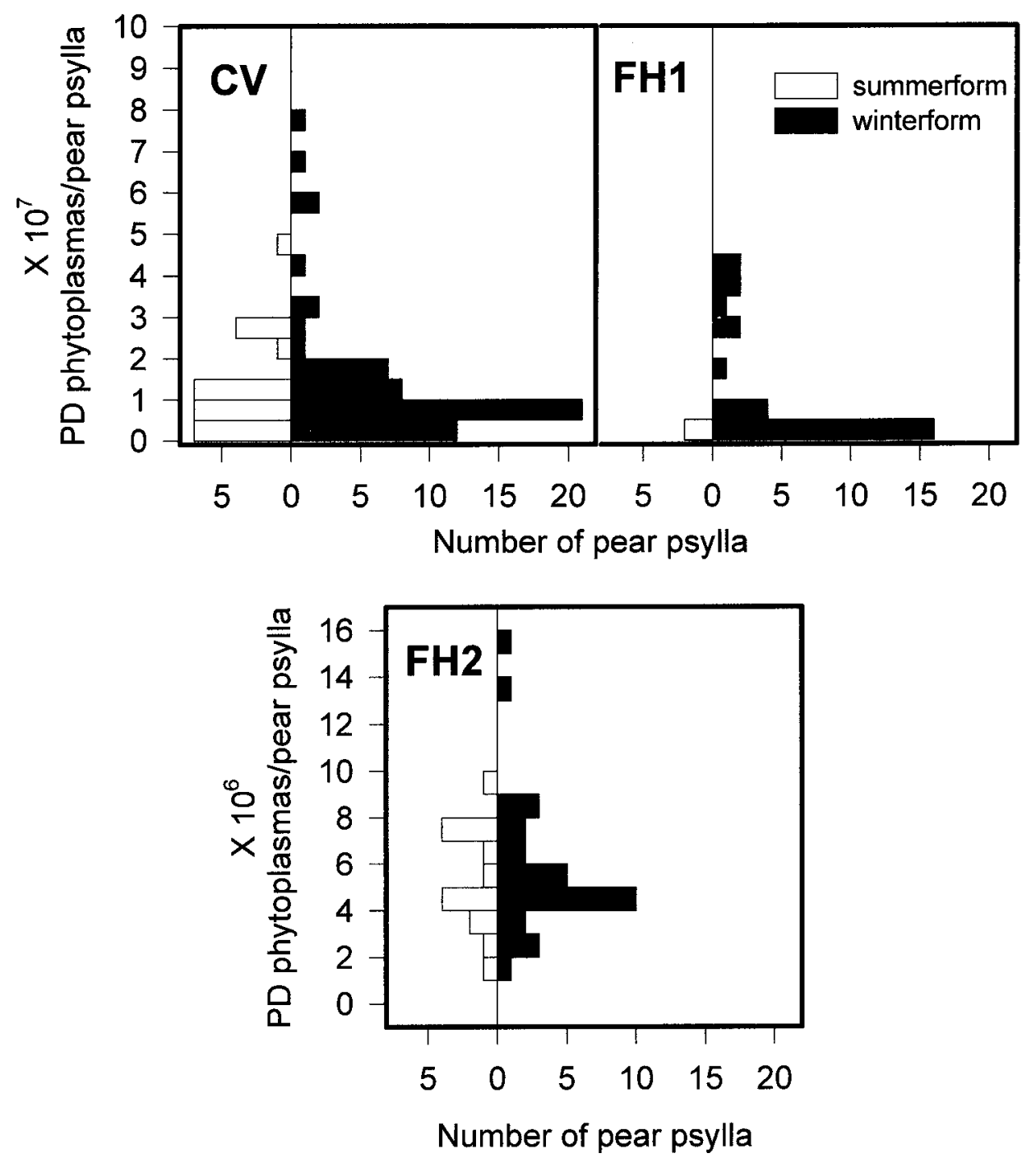

Fig. 7. Histograms representing the distribution of the estimated numbers of pear decline phytoplasmas in hybridization-positive pear psylla populations collected in the Central Valley (CV) and Sierra foothills (FH1 and FH2) orchards over the study period. For psylla collected in the months when both forms were found, those collected in September were considered summerform, and those collected in October and November were considered winterform. Note the different scales on the $y$ axis for FH2. 


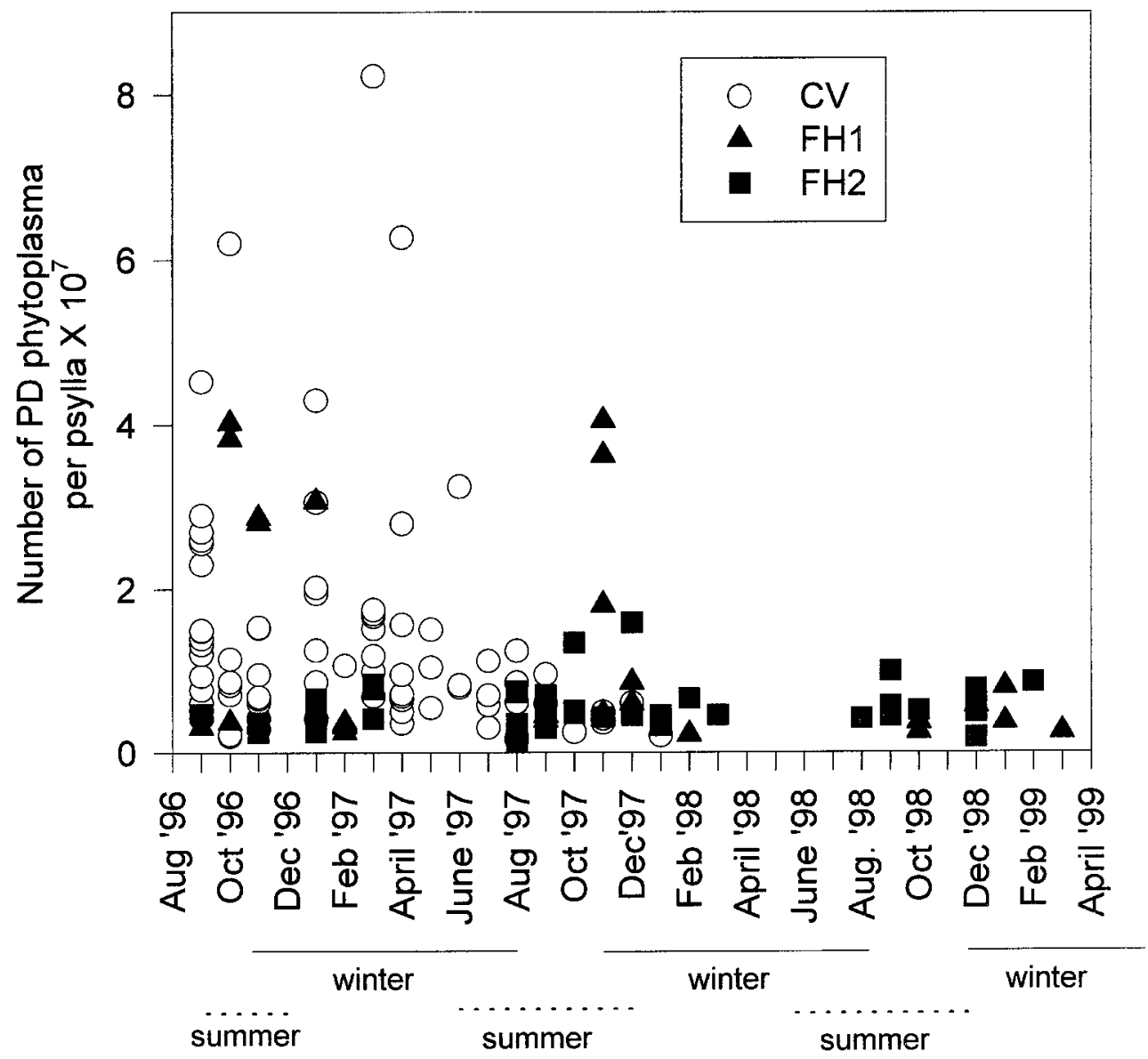

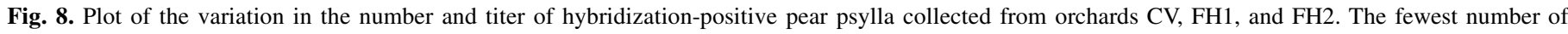

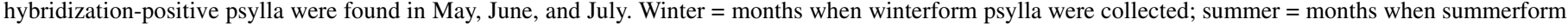
psylla were collected.

was so sensitive that it can even detect gut-limited phytoplasma infections in nonvectors (34). It was interesting to note that in orchard CV, the numbers of PD-positive psylla detected by PCR and DNA hybridization were not statistically different (Table 1). This may be because the PD-infected pear psylla in CV had higher overall pathogen titers than those in the foothill orchards, and therefore, more of these infected psylla were detectable by hybridization analysis.

Hybridization analysis was useful in this study for estimating the number of phytoplasmas in an infected pear psylla. The titers of some plant pathogenic phytoplasmas and spiroplasmas (the latter is a culturable mollicute) in their insect vectors have been estimated using various methods and different vector-phytoplasma species combinations (Table 3). Our estimates of PD phytoplasma titers in pear psylla agree within 1 order of magnitude with the phytoplasma titers found in laboratory-reared leafhoppers infected with other plant pathogenic mollicutes (Table 3). However, the titers we found in pear psylla were considerably less than the numbers of X-disease phytoplasmas that were estimated to be in $P$. irroratus (25). This may be due to the size difference between the pear psylla and P. irroratus, an actual difference in the phytoplasma titers, or a difference in the amount of vector tissues that were systemically infected with X-disease phytoplasma.

The comparatively lower number of PD hybridization-positive psylla detected in May, June, and July may be due to the very low levels of the PD phytoplasma that are present in pear trees in the early summer; PD titers are undetectable in the upper part of the tree until June in California (13). During May to July, only summerform psylla, which emerge from eggs laid on pear trees by winterform psylla, are found on trees. If the acquisition of the PD phytoplasma by the summerform psylla in early summer is delayed due to low titers in the tree during this period, systemic phytoplasma infections of pear psylla, which the DNA hybridization analysis probably detected, will also be delayed. The highest numbers of hybridization-positive insects were collected in September $(n=29)$ and November $(n=22)$ (Fig. 8). During this period, the majority of the psylla were either late summerform (September) or winterform (November). The adults collected in September and November would have been first instar psylla nymphs that emerged at the end of July and the end of September, respectively. The chance of the pear psylla acquiring PD in late summer and early fall is relatively high due to higher pathogen titers in pear trees in July through September (28). The numbers of hybridization-positive psylla were not consistent through the winter. Many winterform psylla leave the orchard in November, so it is possible that in December, the lower numbers of hybridization-positive insects and lower pathogen titers were from a group of developing winterforms that were nymphs when the other earlier-maturing winterforms dispersed. Because the psylla that left the pear orchard in November did not necessarily return to the same orchard in late January (12), it is impossible to know if the differences in the numbers of hybridization-positive psylla during the winter months were due to (i) new immigrants from other orchards that had a different level of PD-infected trees, (ii) if PDinfected insects were more or less likely to survive the winter months than uninfected psylla, or (iii) if PD infection actually influenced the pear psylla's likelihood of dispersing from or returning to the pear orchards. 
TABLE 2. Percent phytoplasma infection of field-collected vectors

\begin{tabular}{lllcl}
\hline Phytoplasma & Vector & Detection method $^{\mathrm{a}}$ & Percent infected $^{\text {Reference }}$ \\
\hline Aster yellows & Macrosteles fascifrons & Biological assay & $4-15 \%$ & Rice-Mahr et al. (26) \\
Blueberry stunt & Scaphytopius spp. & HYB & $3-5 \%$ & Tozzi et al. (33) \\
Flavescence dorée & Scaphoïdeus titanus & ELISA & $22 \%$ & Boudon-Padieu et al. (3) \\
Grapevine yellows & Hyalsesthes osoletus & ELISA, PCR & $7-34 \%$ & Weber and Maixner (35) \\
Pear decline & Cacopsylla pyricola & PCR & $3-5 \%^{\text {b }}$, 17\% & Davies et al. (7) \\
& & PCR & $13.8-19 \%$ & This study \\
Western X-disease & Fieberiella florii, Colladonus montanus, Osbornellus spp. & HYB & $6.4-14.8 \%$ & This study \\
X-disease & Paraphlepsius irroratus & HYB & $2.5 \%$ & Kirkpatrick et al. (17) \\
\hline
\end{tabular}

${ }^{a}$ HYB, DNA hybridization analysis; ELISA, enzyme-linked immunosorbent assay; and PCR, polymerase chain reaction.

${ }^{\mathrm{b}}$ Pear psylla collected from Pyrus communis grafted onto quince rootstock.

${ }^{\mathrm{c}}$ Pear psylla collected from Pyrus communis seedlings.

TABLE 3. Estimates of the number of mollicutes found in both field-harvested and laboratory-reared insect vectors

\begin{tabular}{|c|c|c|c|c|}
\hline Vector & Mollicute & Titer $^{\mathrm{a}}$ & Method $^{\text {b }}$ & Reference \\
\hline Cacopsylla pyricola ${ }^{\mathrm{c}}$ & Pear decline phytoplasma & $1 \times 10^{6}-8.2 \times 10^{7}$ & Hybridization & This study \\
\hline Macrosteles fascifrons ${ }^{\mathrm{d}}$ & Aster yellows phytoplasma & $1 \times 10^{8}$ & PCR & Liu et al. (20) \\
\hline Paraphlepsius irroratus $\mathrm{c}$ & X-disease phytoplasma & $6.6 \times 10^{9}$ & Hybridization & Rahardja et al. (25) \\
\hline Macrosteles fascifrons ${ }^{\mathrm{d}}$ & Spiroplasma citri & $1 \times 10^{6}$ & Direct plating & Whitcomb et al. (38) \\
\hline Euscelis incisus $(=$ E. plebejus $)$ & Spiroplasma citri & $3.7 \times 10^{7}$ & Direct plating & Townsend et al. (32) \\
\hline
\end{tabular}

${ }^{a}$ Titer $=$ estimated number of mollicutes per insect.

${ }^{\mathrm{b}}$ DNA hybridization analysis; PCR, polymerase chain reaction.

${ }^{\mathrm{c}}$ Field-collected insects.

${ }^{\mathrm{d}}$ Laboratory-reared leafhoppers.

Winterform pear psylla can disperse long distances. It took only 18 years (1939 to 1957) for the then newly introduced pear psylla to move from Spokane, WA to San Jose in northern California (36), a distance of 675 miles $(1,086 \mathrm{~km})$. It has been hypothesized that PD came to California on infected nursery stock that was planted in the Sierra Nevada foothills where PD was first detected and not with the apparently uninfected pear psylla that had moved into northern California from Oregon a few years earlier (23). PD then moved with the pear psylla from the Sierra Nevada foothills west to the San Francisco Bay area. In less than 11 years, PD was detected in most pear-growing regions of California (23). With the detection of PD in winterform pear psylla in California and our knowledge of its ability to move long distances, we can now hypothesize that this form was probably responsible for the longdistance spread of PD throughout California.

\section{ACKNOWLEDGMENTS}

This study was funded in part by the University of California Integrated Pest Management program and the California Cling Peach Board. We thank R. L. Gilbertson, D. E. Ullman, D. Cuppels, and the anonymous reviewers for critically reading this manuscript.

\section{LITERATURE CITED}

1. Alivizatos, A. S., and Markham, P. G. 1986. Multiplication of corn stunt spiroplasma in Dalbulus maidis and transmission in vitro, following injection. Ann. Appl. Biol. 108:545-554.

2. Avinent, L., Llacer, G., Almacellas, J., and Tora, R. 1997. Pear decline in Spain. Plant Pathol. 46:694-698.

3. Boudon-Padieu, E., Larrue, J., and Caudwell, A. 1989. ELISA and dotblot detection of flavescence dorée-MLO in individual leafhopper vectors during latency and inoculative state. Curr. Microbiol. 19:357-364.

4. Burts, E. C., and Retan, A. H. 1973. Detection of pear psylla. Wash. State Coop. Ext. Ser. Man. 3069.

5. Carraro, L., Loi, N., Ermacora, A., Gregoris, A., and Osler, R. 1998. Transmission of pear decline by using naturally infected Cacopsylla pyri L. Acta Hortic. 472:665-668.

6. Chen, K. H., Guo, J. R., Wu, X. Y., Loi, L., Carraro, L., Guo, Y. H., Chen, Y. D., Osler, R., Pearson, R., and Chen, T. A. 1993. Comparison of monoclonal antibodies, DNA probes, and PCR for detection of the grapevine yellows disease agent. Phytopathology 83:915-922.
7. Davies, D. L., Barbara, D. J., and Clark, M. F. 1995. The detection of MLOs associated with pear decline in pear trees and pear psyllids by polymerase chain reaction. Acta Hortic. 386:484-488.

8. Davies, D. L., Clark, M. F., and Adams, A. N. 1998. The epidemiology of pear decline in the UK. Acta Hortic. 472:669-672.

9. Davies, D. L., and Eyre, S. 1996. Detection of phytoplasmas associated with pear decline in pear psylla by polymerase chain reaction. Pages 6772 in: Diagnostics in Crop Protection. Proc. Brit. Crop Prot. Symp. Vol. 65.

10. Davies, D. L., Guise, C. M., Clark, M. F., and Adams, A. N. 1992. Parry's disease of pears is similar to pear decline and is associated with mycoplasma-like organisms transmitted by Cacopsylla pyricola. Plant Pathol. 41:195-203.

11. Feinberg, A. P., and Vogelstein, B. 1983. A technique for radiolabeling DNA restriction endonuclease fragments to high specific activity. Anal. Biochem. 132:6-13.

12. Fye, R. E. 1983. Dispersal and winter survival of the pear psylla. J. Econ. Entomol. 76:311-315.

13. Guerra, L. J. 1997. Biological and molecular characterization of phytoplasmas infecting fruit and nut trees in California. Ph.D. thesis. University of California, Davis.

14. Horton, D. R., Higbee, B. S., Unruh, T. R., and Westigard, P. H. 1992. Spatial characteristics and effects of fall density and weather on overwintering loss of pear psylla Homoptera Psyllidae. Environ. Entomol. 21:1319-1332.

15. Jensen, D. D., Griggs, W. H., Gonzales, C. Q., and Schneider, H. 1964. Pear decline virus transmission by pear psylla. Phytopathology 54:13461351.

16. Johnston, R. F., Pickett, S. C., and Barker, D. L. 1990. Autoradiography using storage phosphor technology. Electrophoresis 11:355-360.

17. Kirkpatrick, B. C., Fisher, G. A., Fraser, J. D., and Purcell, A. H. 1990. Epidemiological and phylogenetic studies on western X-disease mycoplasma-like organisms. Pages 288-296 in: Recent Advances in Mycoplasmology. G. Stanek, G. H. Cassell, J. G. Tully, and R. F. Whitcomb, eds. Gustav Fisher Verlag, New York.

18. Kirkpatrick, B. C., Stenger, D. C., Morris, T. J., and Purcell, A. H. 1987. Cloning and detection of DNA from a nonculturable plant pathogenic mycoplasma-like organism. Science 238:197-200.

19. Krysan, J. L., and Higbee, B. S. 1990. Seasonality of mating and ovarian development in overwintering Cacopsylla pyricola (Homoptera: Psyllidae). Environ. Entomol. 19:544-550.

20. Liu, H. W., Goodwin, P. H., and Kuske, C. R. 1994. Quantification of DNA from the aster yellows mycoplasmalike organism in aster leafhoppers (Macrosteles fascifrons Stål) by a competitive polymerase chain reaction. Syst. Appl. Microbiol. 17:274-280.

21. Lorenz, K. H., Schneider, B., Ahrens, U., and Seemuller, E. 1995. Detection of the apple proliferation and pear decline phytoplasmas by PCR 
amplification of ribosomal and nonribosomal DNA. Phytopathology 85:771-776.

22. Madsen, H. F., and Barnes, M. M. 1959. Pests of pear in California. Calif. Agric. Exp. Stn. Circ. 478.

23. Nichols, C. W., Blanc, F. L., Mellican, A. A., and Barbe, D. G. 1965. A new explanation of the spread of pear psylla and pear decline virus in California. Calif. Dep. Agric. Bull. 54:133-144.

24. Oldfield, G. N. 1970. Diapause and polymorphism in California populations of Psylla pyricola (Homoptera: Psyllidae). Ann. Entomol. Soc. Am. 63:180-184.

25. Rahardja, U., Whalon, M. E., Garcia-Salazar, C., and Yan, Y. T. 1992. Field detection of X-disease mycoplasma-like organism in Paraphlepsius irroratus (Say) (Homoptera: Cicadellidae) using a DNA probe. Environ. Entomol. 21:81-88.

26. Rice-Mahr, S. E., Wyman, J. A., and Chapman, R. K. 1993. Variability in aster yellows infectivity of local populations of the aster leafhopper (Homoptera: Cicadellidae) in Wisconsin. J. Econ. Entomol. 86:15221526.

27. Sambrook, J., Fritsch, E. F., and Maniatis, T. 1989. Molecular Cloning: A Laboratory Manual. 2nd ed. Cold Spring Harbor Laboratory, Cold Spring Harbor, NY.

28. Seemüller, E. 1988. Colonization patterns of mycoplasmalike organisms in trees affected by apple proliferation and pear decline. Pages 179-192 in: Tree Mycoplasmas and Mycoplasma Disease. C. Huruki, ed. University of Alberta Press, Edmonton, Alberta.

29. Seemüller, E., Lorenz, K.-H., and Lauer, U. 1998. Pear decline resistance in Pyrus communis rootstocks and progenies of wild and ornamental Pyrus taxa. Acta Hortic. 472:681-691.

30. Smart, C. D., Schneider, B., Blomquist, C. L., Guerra, L. J., Harrison, N.
A., Ahrens, U., Lorenz, K. H., Seemüller, E., and Kirkpatrick, B. C. 1996. Phytoplasma-specific PCR primers based on sequences of the $16 \mathrm{~S}$ 23S rRNA spacer region. Appl. Environ. Microbiol. 62:2988-2993.

31. Snedecor, G. W., and Cochran, W. G. 1980. Statistical Methods. The Iowa State University Press, Ames.

32. Townsend, R., Markham, P. G., and Plaskitt, K. A. 1977. Multiplication of Spiroplasma citri in the leafhopper Euscelis plebejus. Ann. Appl. Biol. 87:307-313

33. Tozzi, D. C. M., Ramsdell, D. C., Taboada, O., Lee, I.-M., and Davis, R. E. 1993. Epidemiological studies on the stunt disease of the highbush blueberry. Ann. Appl. Biol. 123:579-599.

34. Vega, F. E., Davis, R. E., Barbosa, P., Dally, E. L., Purcell, A. H., and Lee, I.-M. 1993. Detection of a plant pathogen in a nonvector insect species by the polymerase chain reaction. Phytopathology 83:621-624.

35. Weber, A., and Maixner, M. 1998. Survey of populations of the planthopper Hyalesthes obsoletus sign. (Auchenorrhyncha, Cixiidae) for the infection with the phytoplasma causing grapevine yellows in Germany. J. Appl. Entomol. 122:375-381.

36. Westigard, P. H., and Zwick, R. W. 1972. The pear psylla in Oregon. Oreg. State Univ. Agric. Exp. Stn. Tech. Bull. 122:1-21.

37. Westwood, M. N., Cameron, H. R., Lombard, P. B., and Cordy, C. B. 1971. Effects of trunk and rootstock on decline, growth and performance of pear. J. Am. Soc. Hortic. Sci. 96:147-150.

38. Whitcomb, R. F., Tully, J. G., Bove, J. M., and Saglio, P. 1973. Spiroplasmas and acholeplasmas: Multiplication in insects. Science 182:12511252.

39. Zhang, Y.-P., Uyemoto, J. K., and Kirkpatrick, B. C. 1998. A small-scale procedure for extracting nucleic acids from woody plants infected with various phytopathogens for PCR assay. J. Virol. Methods 71:45-50. 